\title{
The Usage of Technology-Enabled Marketing Tools by SMEs and Their Bankruptcy Concerns: Evidence from Visegrad Countries
}

\author{
Mehmet CIVELEK ${ }^{1}$, Aleksandr KLJUČNIKKOV ${ }^{2}$, Vladimír VAVREČKA ${ }^{3}$ and \\ Krzysztof GAJDKA ${ }^{4}$
}

Authors' affiliations and addresses:

${ }^{1}$ Institute of Entrepreneurship and Marketing,

University of Entrepreneurship and Law,

Michálkovická 1810/181, 71000 Ostrava-Slezská

Ostrava, Czech Republic

e-mail: $\underline{m \text { civelek@windowslive.com }}$

${ }^{2}$ Institute of Entrepreneurship and Marketing,

University of Entrepreneurship and Law,

Michálkovická 1810/181, 71000 Ostrava-Slezská

Ostrava, Czech Republic

e-mail: kliuchnikov@gmail.com

${ }^{3}$ Institute of Entrepreneurship and Marketing,

University of Entrepreneurship and Law,

Michálkovická 1810/181, 71000 Ostrava-Slezská

Ostrava, Czech Republic

e-mail: vavreckav@vspp.cz

${ }^{4}$ Institute of Entrepreneurship and Marketing,

University of Entrepreneurship and Law,

Michálkovická 1810/181, 71000 Ostrava-Slezská

Ostrava, Czech Republic

e-mail: gajdka@vspp.cz

*Correspondence:

Mehmet Civelek, Institute of Entrepreneurship and Marketing, University of Entrepreneurship and Law, Michálkovická 1810/181, 71000 Ostrava-Slezská Ostrava, Czech Republic tel.: +420773873403

e-mail: m civelek@windowslive.com

How to cite this article:

Civelek, M., Ključnikov, A., Vavrečka, V. and Gajdka, K. (2020). The Usage of TechnologyEnabled Marketing Tools by SMEs and Their Bankruptcy Concerns: Evidence from Visegrad Countries. Acta Montanistica Slovaca, Volume 25 (3), 263-273

DOI:

https://doi.org/10.46544/AMS.v25i3.01

\begin{abstract}
SMEs are essential players for iron and mining industries that create high value-added products for economies. However, since these businesses lack financial assets compared with larger enterprises, they are more likely to be in bankruptcy. Since technology-enabled marketing channels might increase sales, revenues, and performance of these businesses, they might provide SMEs with opportunities to cope with bankruptcy problems. In this regard, this paper aims to investigate and explore whether the usage of technology-enabled marketing tools by SMEs reduce their probabilities to face bankruptcies or not. Moreover, as age and size are determinant factors for firms' survival, this paper also considers these variables in the analyses. The researchers employed a questionnaire to collect data from 1156 Czech, Slovak, and Hungarian SMEs operating in various industries such as iron and mining to hit these targets. To make the analyses, the researchers perform Binary Logistic Regression analyses in SPSS statistical program. These analyses prove the nonexistence of the association between the usage of technology-enabled marketing tools and firm bankruptcies. This statement is valid for companies of any age and size. On the other hand, the research finds some significant results regarding the firm's specific characteristics and bankruptcies. These results differ in a country-based context. These results might be related to the volume of financing for SMEs, the industry that SMEs operate, and the age and managerial experiences of owners/managers. The implementations of policymakers, such as having better bankruptcy laws and policymakers' collaborations with other players such as universities, might decrease the volume of bankruptcies and stimulate the use of technology-enabled marketing channels by SMEs.
\end{abstract}

\section{Keywords}

technology-enabled marketing tools, bankruptcy, age, size, SMEs, Czechia, Slovakia, Hungary 


\section{Introduction}

Small and medium-sized enterprises (SMEs) serve a fundamental purpose for the economy's development since they help countries overcome unemployment problems and create high value-added products such as iron and mine. For instance, 17500 SMEs operating in mining and quarrying employ 413000 people in the EU (Eurostat Statistics, 2017). However, compared to larger SMEs, the number of SMEs that go to bankruptcy is greater than the larger firms because SMEs have lower financial assets and financial power than their larger counterparts, which increases the concerns of many entrepreneurs regarding their survival. In this context, the usage of technology-enabled marketing channels might enable SMEs to survive by overcoming bankruptcy issues since a positive relationship exists between adopting marketing technology channels by SMEs and their growth (Eze et al., 2019; Amjad et al., 2020).

In this regard, this paper aims to analyze whether the usage of technology-enabled marketing tools by SMEs makes them prevent themselves from bankruptcy. The researchers separately analyzed 1156 SMEs from the Czech Republic, Slovakia, and Hungary regarding their operational location to fulfill this aim. According to Dvorsky et al. (2020), every fifth business in the South Moravian Region, every sixth company in the Czech Republic's Prague regions, and similarly, every sixth firm in Slovakia has bankruptcy risk. Thus, analyzing this fact in different countries and SMEs from the mining and iron industries might make this paper create value addition for academic literature.

Technology-enabled marketing tools consist of internet platforms such as websites and e-mails (Kumar et al., 2015; Taiminen \& Karjaluoto, 2015) that make SMEs have easier access to different markets (Madill et al., 2010). Moreover, these platforms enable SMEs' opportunities, such as making advertising and sales activities (Kumar et al., 2015) and providing some information about their goods and services to their local, global customers (Madill et al., 2010). Technology-enabled marketing channels provide less costly business solutions regarding their marketing activities than traditional marketing methods (Amjad et al., 2020). Concerning bankruptcy, it is an undesirable status for businesses since they cannot pay their debt and fulfill their liabilities (Svabova et al., 2020; Tobback et al., 2017). Financial risks (Hudakova et al., 2018; Kozubikova et al., 2017) such as the lower amount of working capital (Dvorsky et al., 2019), and assets (Milosevic et al., 2019), poor risk management (Khan et al., 2020; Belas et al., 2020), lack of planning (Ajaz Khan et al., 2019), the efficiency of legal, political, and financial environments (Mc Namara et al., 2019) are some of the main reasons for businesses' bankruptcies and failures.

On the other hand, firm characteristics such as age and size have also been considered as determinant factors for success (Mabenge et al., 2020), performance (Mabenge et al., 2020; Soltani et al., 2013), the usage of digital marketing channels (Taiminen \& Karjaluoto, 2015), failure and bankruptcy of firms (Susi \& Lukason, 2019; Higashi et al., 2020). Therefore, this paper also considers the firms' specific factors such as age (the length of doing business) and size to examine whether these variables are determinant factors in the relationship between SMEs' bankruptcy and their usage of technology-enabled marketing tools. In this regard, the research questions might arise: Does the usage of technology-enabled marketing tools by SMEs decrease their probabilities to go to bankruptcy? Moreover, this paper also tries to answer the following research question: whether the usage of technology-enabled marketing tools by SMEs decrease their probabilities to go to bankruptcy depending on their size and age?

The remaining sections of this paper are structured as follows. Material and Methods clarify the creation of hypotheses and the methodological approaches that the researchers follow. Section 3 gives details about this paper's results, while section 4, Discussion, highlights the main findings, potential reasons for these results, and suggestions of the researchers related to policy implications. In section 5, the paper summarizes the major vital points of the paper and mentions the limitations of this research.

\section{Material}

\section{Material and Methods}

When using mobile marketing tools, SMEs can apply for some promotions and provide more products and services that increase their sales and revenues (Eze et al., 2019). Therefore, firms are more likely to face bankruptcy problems if they lack marketing activities (Milosevic et al., 2019). Moreover, Wei et al. (2018) highlight that enterprises' lack of online platform usage might make them experience bankruptcy issues. Similarly, Amjad et al. (2020) state that one of the reasons for enterprises' failure is the lack of entrepreneurial activities regarding marketing. Pineiro-Sanchez (2020) also emphasizes the importance of using marketingoriented IT resources to survive businesses. Moreover, businesses' inefficient marketing and management strategies and marketing investments might be the reasons for business failures (Dvorsky et al., 2020). By considering the above empirical studies, one of the hypotheses is as follows:

H1: There is a negative relationship between the use of technology-enabled marketing tools by SMEs and their bankruptcy. 
Since smaller firms have lower financial power (Higashi et al., 2020), assets (Higashi et al., 2020; Lucanera et al., 2020), profitability, and reduced opportunities to receive external finance (Lucanera et al., 2020), they are more likely to go bankrupt in comparison with larger businesses (Cultrera \& Bredart, 2016; Higashi et al., 2020; Lucanera et al., 2020).

Similarly, due to more financial power, assets, and competencies, larger firms are more likely to be aware of market opportunities. They can receive more benefits from these opportunities by hiring talented employees who can create new devices, IT programs, and new technological initiatives (Delerue \& Cronje, 2015). For this reason, compared to smaller firms, larger firms are also more open to changes, new technological tools, innovative actions such as usage of innovative marketing tools, and applying more activities regarding marketing innovation (Delerue \& Cronje, 2015; Mabenge et al., 2020; Rasiah et al., 2010). In this regard, using technologyenabled marketing tools and social media channels by larger firms is more available for these enterprises than their smaller counterparts. Since SMEs have more abilities, competencies, and resources, they are more likely to use the technology-enabled marketing tools to have more revenues and face lower probabilities of being bankrupt. All these facts mentioned above make this paper set a hypothesis as follows:

H2: A negative association exists between using technology-enabled marketing tools by larger sized SMEs and their bankruptcy.

Since older firms have more abilities, competencies, and experiences (Dobbs et al., 2014; Higashi et al., 2020), they can have more revenues, assets, and lower debts (Lucanera et al., 2020). Therefore, they are more likely to survive (Higashi et al., 2020) and less likely to go bankrupt than their younger counterparts (Cultrera \& Bredart, 2016; Lucanera et al., 2020).

On the other hand, compared to younger firms, older SMEs have more abilities to perform innovative activities since they have already set a relationship by setting mutual trust with market agents and have had more strategies to apply on their goods' or services' development (Exposito et al., 2019). Moreover, by operating for a longer time in the markets, they have had more experience making investments for novel technologies (Delerue \& Cronje, 2015), such as using technology-enabled marketing tools. As highlighted by the mentioned studies, having more experiences, capabilities regarding marketing and innovative actions and incomes and assets might make older SMEs more likely to use technology-enabled marketing tools and be less likely to face bankruptcies. Thus, this paper sets another hypothesis as follows:

H3: A negative association exists between the use of technology-enabled marketing tools by older SMEs and their bankruptcy.

\section{Methods}

This research examines the impacts of using technology-enabled marketing tools on SMEs' bankruptcy depending on their characteristics. To achieve this goal, the researchers collected the research data from September 2019 to March 2020 by employing a questionnaire survey. The researchers performed a random sampling method to choose survey participants from the Cribis database. After that, the researchers shared the link of the online questionnaire with the survey participants via e-mails. 1156 respondents who are owners and managers of the selected SMEs have fulfilled the survey. In detail, the sample of the analysis consists of 454 Czech, 303 Slovak, and 399 Hungarian SMEs.

The following questions evaluated one of the independent variables, namely, usage of technology-enabled marketing tools by SMEs: "Our company primarily uses proactive sales mix tools - direct mailing, SMS campaigns, telemarketing"; "Our company primarily uses online marketing tools - modern websites, banner advertising, PPC (PPA) campaigns, Google Adwords, Adwords"; "We consider the active use of online marketing tools to be the most crucial factor in reducing the likelihood of business failure". The researchers used a five-point Likert scale to assess the responses from the questions mentioned above: 1 - strongly disagree, 2 disagree, 3 - hold no position, 4 -agree, 5 - strongly agree. On the other hand, the dependent variable of the research models was measured by the following dichotomous survey question: "Has your company gone to bankruptcy (under bankruptcy we understand a critical situation that has had a significant impact on the company's activities: bankruptcy, company reorganization, and others?)". The possible answers for this question were "Yes" or "No" due to having a binary dependent variable. If the respondents select the "Yes" answer to this question, their companies have experienced bankruptcy vice versa. Therefore, to analyze whether independent variables influence dependent variables, the researchers perform Binary Logistic Regression Test. The researchers performed all analyses of this paper via the SPSS statistical program. For analysis purposes, firm age and size are categorized into two groups as older-younger firms (firms that have been operating for ten or more years or less) and larger-smaller firms (firms that are under small-medium sized enterprises, have a minimum of 10 workers and microenterprises that have less than ten employees).

The results of the empirical studies that are mentioned in the literature review section make the researchers assume the following hypotheses as follows:

H1: There is a negative relationship between the use of technology-enabled marketing tools by SMEs and their bankruptcy. 
H2: A negative association exists between using technology-enabled marketing tools by larger sized SMEs and their bankruptcy.

H3: A negative association exists between the use of technology-enabled marketing tools by older SMEs and their bankruptcy.

The scholars consider a 5\% level of significance to support or fail to support alternative and null hypotheses. Therefore, the researchers fail to support alternative hypotheses when having $p$ values higher than this selected significance level. Logistic regression models of this research for the H1 hypothesis is as follows: $1^{\text {st }}$ Binary Logistic regression model: $Y_{l}=\left(\beta_{0}+\beta_{l} X_{l}\right)$ where:

$X_{1}$ - Independent variable (usage of technology-enabled marketing tools);

$Y_{1}-$ Dependent variable (bankruptcy of SMEs);

$B_{1}-$ Regression coefficients;

$\beta_{0}-$ Constant or intercept term.

Regarding the $\mathrm{H} 2$ hypothesis, firm size is included in the $2^{\text {nd }}$ Binary Logistic regression model as follows: $2^{\text {nd }}$ Binary Logistic regression model: $Y_{1}=\left(\beta_{0}+\beta_{1} X_{1}+\beta_{2} X_{2}\right)$ where: $Y_{1}$ - Dependent variable (bankruptcy of SMEs);

$X_{1}$ - Independent variable (usage of technology-enabled marketing tools);

$X_{2}$ - Independent variable (firm size)

$B_{1,2}-$ Regression coefficients;

$\beta_{0}-$ Constant or intercept term.

Regarding the $\mathrm{H} 3$ hypothesis, the researchers have added firm age as an independent variable to $3^{\text {rd }}$ Binary Logistic regression model as follows:

$3^{\text {rd }}$ Binary Logistic regression model: $Y_{l}=\left(\beta_{0}+\beta_{1} X_{1}+\beta_{2} X_{2}\right)$

where:

$Y_{1}$ - Dependent variable (bankruptcy of SMEs);

$X_{1}$ - Independent variable (usage of technology-enabled marketing tools);

$X_{2}$ - Independent variable (firm age)

$B_{1,2}-$ Regression coefficients;

$\beta_{0}-$ Constant or intercept term.

To analyze whether the Independence of errors assumption of the created logistic regression models are fulfilled or not, the researchers employ Durbin Watson test statistics. This assumption aims to indicate if a relationship between the cases and the data exists; therefore, the residual terms should not be dependent and autocorrelated (Field, 2009, p. 220). Durbin-Watson Statistic values commonly differ from 0 to 4, but the values around 2 indicate the nonexistence of autocorrelation between residual terms. The results from Durbin-Watson Statistic differ from 1,973 to 2,051, and they are close to 2. These results make this paper fulfill the independence of errors assumption for the above-mentioned logistic regression models.

Regarding another assumption of Logistic regression, namely, multicollinearity, this paper considers both indicators, Variance inflation factors (VIF) and tolerance volumes. However, since Model 1 has only an independent variable, this paper only measures multicollinearities between the independent variables of Model-2 and Model-3. When the values from tolerance are higher than 0.10 and VIF scores are lower than 10 , it can be confirmed that multicollinearities between independent variables are not in existence. Since the tolerance values (around 0.983 to 0.990 ) are higher than the threshold mentioned above and VIF scores are lower than 10 (differ from 1,010 to 1,019 ), there are not multicollinearities between the independent variables (firm age, firm size, usage of technology-enabled marketing tools) of second and third logistic regression models.

On the other hand, to measure the linearity assumption of logistic regression, "interaction term between the predictor and its log transformation" (Field, 2009, p.273) is considered by the researchers. To fulfill the linearity assumption requirement, interaction terms (Sig. in Table 1) need to be greater than a 5\% significance level. As indicated in the table, interaction terms differ between 0.186 and 0,940 . To sum up, since the paper fulfills the logistic regression test requirements, it does not violate any assumptions. 
Tab. 1. Linearity Assumption for the Logistic Regression Models

\begin{tabular}{|c|c|c|c|c|c|c|}
\hline Variable & B & S.E. & Wald & $\mathrm{df}$ & Sig. & $\operatorname{Exp}(B)$ \\
\hline \multicolumn{7}{|c|}{ LOGISTIC REGRESSION MODEL-1 } \\
\hline $\begin{array}{l}\text { mar by mark } \\
\text { Czechia }\end{array}$ &,- 050 & ,112 & ,201 & 1 & 654 & ,951 \\
\hline Slovakia & ,163 &, 186 &, 771 & 1 &, 380 & 1,177 \\
\hline Hungary &,- 034 &, 170 &, 039 & 1 &, 843 & ,967 \\
\hline \multicolumn{7}{|c|}{ LOGISTIC REGRESSION MODEL-2 } \\
\hline $\begin{array}{l}\text { mar by mark. } \\
\text { Czechia }\end{array}$ &,- 212 & ,161 & 1,746 & 1 & ,186 & ,809 \\
\hline Slovakia & , 199 &, 265 &, 562 & 1 & 453 & 1,220 \\
\hline Hungary &,- 077 & ,229 &, 114 & 1 & ,736 & ,926 \\
\hline $\begin{array}{l}\text { size by size } \\
\text { Czechia }\end{array}$ & ,057 & ,106 & ,291 & 1 & ,590 & 1,059 \\
\hline Slovakia & ,089 &, 170 &, 276 & 1 &, 600 & 1,093 \\
\hline Hungary & ,012 &, 163 &, 006 & 1 &, 940 & 1,012 \\
\hline \multicolumn{7}{|c|}{ LOGISTIC REGRESSION MODEL-3 } \\
\hline $\begin{array}{l}\text { mar by mark. } \\
\text { Czechia }\end{array}$ & ,165 & ,283 & ,339 & 1 &, 561 & 1,179 \\
\hline Slovakia &, 157 &, 353 & ,198 & 1 &, 657 & 1,170 \\
\hline Hungary &,- 891 & ,688 & 1,675 & 1 & ,196 & ,410 \\
\hline $\begin{array}{l}\text { age by age } \\
\text { Czechia }\end{array}$ & ,204 & 286 &, 511 & 1 & ,475 & 1,226 \\
\hline Slovakia & ,009 &, 364 &, 001 & 1 & ,981 & 1,009 \\
\hline Hungary & , 108 &, 218 &, 247 & 1 & ,620 & 1,114 \\
\hline
\end{tabular}

Source: own calculations.

Regarding sample size, Long (1997) emphasizes the fact that 100 respondents will be enough for each independent variable to have the required sample size for logistic regression models. The researchers' models have a maximum of two independent variables; thus, 200 respondents can be enough to apply logistic regression analyses. Since the paper has three different samples from the 454 Czech, 303 Slovak, and 399 Hungarian SMEs, this research has fulfilled the sample size's logistic regression requirement. Moreover, these samples do not have any repeated and matched data. The sample profile is illustrated in Table 2 as follows:

\begin{tabular}{|c|c|c|c|c|c|c|c|}
\hline & & \multicolumn{2}{|c|}{ Czech } & \multicolumn{2}{|c|}{ Slovak } & \multicolumn{2}{|c|}{ Hun } \\
\hline & & $n$ & Share & $n$ & Share & $n$ & Share \\
\hline \multirow{4}{*}{ Firm size } & micro & 290 & $63.88 \%$ & 171 & $56.44 \%$ & 268 & $67.17 \%$ \\
\hline & small & 107 & $23.57 \%$ & 90 & $29.70 \%$ & 73 & $18.29 \%$ \\
\hline & medium & 57 & $12.55 \%$ & 42 & $13.86 \%$ & 58 & $14.54 \%$ \\
\hline & Total & 454 & $100 \%$ & 303 & $100 \%$ & 399 & $100 \%$ \\
\hline \multirow{4}{*}{ Firm age } & up to 5years & 55 & $12.11 \%$ & 43 & $14.19 \%$ & 85 & $21.30 \%$ \\
\hline & 6 to 10 years & 64 & $14.10 \%$ & 44 & $14.52 \%$ & 62 & $15.54 \%$ \\
\hline & more than 10 years & 335 & $73.79 \%$ & 216 & $71.29 \%$ & 252 & $63.16 \%$ \\
\hline & Total & 454 & $100 \%$ & 303 & $100 \%$ & 399 & $100 \%$ \\
\hline \multirow{5}{*}{$\begin{array}{c}\text { Legal } \\
\text { Structure }\end{array}$} & sole proprietorship & 135 & $29.74 \%$ & 50 & $16.50 \%$ & 109 & $27.32 \%$ \\
\hline & limited liability & 266 & $58.59 \%$ & 221 & $72.94 \%$ & 240 & $60.15 \%$ \\
\hline & joint-stock company & 34 & $7.49 \%$ & 16 & $5.28 \%$ & 18 & $4.51 \%$ \\
\hline & other & 19 & $4.18 \%$ & 16 & $5.28 \%$ & 32 & $8.02 \%$ \\
\hline & Total & 454 & $100 \%$ & 303 & $100 \%$ & 399 & $100 \%$ \\
\hline
\end{tabular}

Source: own calculations. 


\section{Results}

The results of Binary Logistic Regression analyses regarding Model-1 for each nation are separately demonstrated in Table 3. As already specified in the Methodology section, Model-1 only includes using technology-enabled marketing tools as an independent variable. The paper employs Wald statistics to determine if this independent variable (predictor variable) is significant to predict the dependent variable and significantly contributes to the dependent variable (Field, 2009).

Tab. 3. The results of Binary Logistic Regression Analyses for Model-1

\begin{tabular}{|c|c|c|c|c|c|c|c|}
\hline Country & Variable & B & SE & OR & $95 \%$ CI & $\begin{array}{c}\text { Wald } \\
\text { statistic }\end{array}$ & $p$ \\
\hline \multirow[t]{3}{*}{ Czechia } & Marketing &,- 050 & 0.112 & 0.951 & {$\left[\begin{array}{lll}0.763 & 1.185\end{array}\right]$} & 0.201 & 0.654 \\
\hline & Constant & -1.339 & 0.310 & 0.262 & & 18.640 & 0.000 \\
\hline & \multicolumn{7}{|c|}{ Model-1: Bankruptcy $=-1.339-0.050 *$ marketing } \\
\hline \multirow[t]{3}{*}{ Slovakia } & Marketing & , 163 & 0.186 & 1.177 & {$\left[\begin{array}{lll}0.818 & 1.693\end{array}\right]$} & 0.771 & 0.380 \\
\hline & Constant & -2.064 & 0.559 & 0.127 & & 13.618 & 0.000 \\
\hline & \multicolumn{7}{|c|}{ Model-1: Bankruptcy $=-2.064+0.163 *$ marketing } \\
\hline \multirow[t]{3}{*}{ Hungary } & Marketing &,- 034 & 0.170 & 0.967 & {$\left[\begin{array}{lll}0.693 & 1.349\end{array}\right]$} & 0.039 & 0.843 \\
\hline & Constant & -1.937 & 0.529 & 0.144 & & 13.618 & 0.000 \\
\hline & \multicolumn{7}{|c|}{ Model-1: Bankruptcy $=-1.937-0.034 *$ marketing } \\
\hline
\end{tabular}

$\beta$ scores for Model-1 for Czech SMEs, Slovak SMEs and Hungarian SMEs are -,050, 0,163, -,034, respectively (Czech SMEs: $\beta=-, 050$, Wald $\chi^{2}=0.201, p=0.654>0.05$; Slovak SMEs: $\beta=0,163$, Wald $\chi^{2}=$ $0.771, p=0.380>0.05$; Hungarian SMEs: $\beta=-, 034$, Wald $\left.\chi^{2}=0.039, p=0.843>0.05\right)$. The values of $\beta$ coefficients substantiate the fact that the use of technology-enabled marketing tools by SMEs is not a significant predictor to estimate whether SMEs go to bankruptcy or not. Thus, there is no statistically significant impact of usage of technology-enabled marketing on SMEs' bankruptcies. According to the table, all $p$ values are higher than the 5\% significance level, so the independent variable's coefficients are not significantly different from 0. Even firms use technology-enabled marketing tools, their probabilities to go bankrupt neither increase nor decrease. In other words, when SMEs apply activities that enable them to use technology-enabled marketing tools, they are no less or more likely to go to bankruptcy. Therefore, this paper fails to support the H1 hypothesis that presumes the negative relationship between technology-enabled marketing tools' usage and firms' bankruptcy.

When Model-2 is considered, technology-enabled marketing tools and firm size are independent variables, while the dependent variable is bankruptcy. The results from logistic regression analyses regarding Model-2 are illustrated below in Table 4 .

Tab. 4. The results of Binary Logistic Regression Analyses for Model-2

\begin{tabular}{|c|c|c|c|c|c|c|}
\hline Country & Variable & B & SE & $95 \% \mathrm{CI}$ & $\begin{array}{c}\text { Wald } \\
\text { statistic }\end{array}$ & $p$ \\
\hline \multirow[t]{4}{*}{ Czechia } & Marketing &,- 063 & ,113 & ,939 $\left[\begin{array}{ll}, 752 & 1,172]\end{array}\right.$ & ,311 & 577 \\
\hline & Firm size &, 511 & ,244 & $1,668[1,0332,692]$ & 4,378 & ,036 \\
\hline & Constant & $-2,021$ & ,457 & 133 & 19,547 &, 000 \\
\hline & \multicolumn{6}{|c|}{ Model-2: Bankruptcy $=-2.021-0.063 *$ marketing $+0.511 *$ firm size } \\
\hline \multirow[t]{4}{*}{ Slovakia } & Marketing &, 152 & , 187 & $1,164[, 807 \quad 1,679]$ & ,662 & ,416 \\
\hline & Firm size &,- 726 & ,333 & ,484 [,252 ,929] & 4,759 & 029 \\
\hline & Constant & $-1,033$ & ,720 & ,356 & 2,059 &, 151 \\
\hline & \multicolumn{6}{|c|}{ Model-2: Bankruptcy $=-1.033+0.152 *$ marketing $-0.726 *$ firm size } \\
\hline \multirow[t]{4}{*}{ Hungary } & Marketing &,- 034 & , 170 & ,967 [,693 1,350$]$ & ,039 & ,843 \\
\hline & Firm size &,- 010 & ,334 & ,990 [ [,514 1,908] & ,001 & 977 \\
\hline & Constant & $-1,925$ & 681 & , 146 & 7,986 & 005 \\
\hline & \multicolumn{6}{|c|}{ Model-2: Bankruptcy $=-1.925-0.034 *$ marketing $-0.010 *$ firm size } \\
\hline
\end{tabular}

As indicated in Table 4, technology-enabled marketing tools' usage is not a statistically significant predictor in Model-2 for each nation. This is because $p$ values for this independent variable is greater than 5\% significance level ( $p=0,577,0,416,0,843>0.05$ respectively, for the Czech, Slovak and Hungarian samples). However, when it comes to another independent variable of Model-2, namely, firm size, this research results differ depending on each sample. For instance, while firm size is a significant predictor of bankruptcy of firms for both samples, Czech $(p=0,036<0,05)$ and Slovak $(p=0,029<0,05)$, it is not a significant variable to predict bankruptcy of Hungarian enterprises $(p=0,977>0,05)$. For this reason, firm size does not make a significant 
contribution to the bankruptcy of Hungarian SMEs. Therefore, there is not any significant relationship between the size of Hungarian SMEs and their bankruptcy.

Although firm size makes significant contributions to Czech and Slovak SMEs' bankruptcy, some differences exist for these samples. The coefficient of firm size is positive for Czech SMEs $(\beta=0.511)$, while it is negative for Slovak firms $(\beta=-0,726)$. The volume of the coefficient for Czech SMEs confirms that firm size values are associated with higher possibilities to go to bankruptcy. Thus, larger Czech SMEs are more likely to go to bankruptcy than their smaller-sized counterparts in Czechia. On the other hand, since the firm size coefficient is negative for Slovak SMEs, we can state that smaller Slovak SMEs are more likely to go bankrupt than larger enterprises in Slovakia. Because of having non-significant results from technology-enabled marketing tools usage in Model-2 for Czech and Slovak SMEs and due to having non-significant results for both independent variables in Model-2 for Hungarian SMEs, this research fails to accept the H2 hypothesis that assume the negative association between the usage of technology-enabled marketing tools by larger sized SMEs and their bankruptcy.

As already mentioned, Model-3 has two independent variables: technology-enabled marketing tools' usage and firm age. Table 5 demonstrates the results of Binary Logistic Regression analyses for Model-3. Like both models, Model-1 and Model-2, usage of technology-enabled marketing tools is not a significant variable to predict SMEs' bankruptcy for Model-3, too. This because $\mathrm{p}$ values for this variable is higher than the selected level of significance $(p=0,699,0,418,0,949>0.05$ respectively, for the Czech, Slovak and Hungarian samples).

Tab. 5. The results of Binary Logistic Regression Analyses for Model-3

\begin{tabular}{|c|c|c|c|c|c|c|c|}
\hline Country & Variable & B & SE & OR & $95 \% \mathrm{CI}$ & $\begin{array}{c}\text { Wald } \\
\text { statistic }\end{array}$ & $p$ \\
\hline \multirow[t]{4}{*}{ Czechia } & Marketing &,- 044 & ,113 & 957 & {$[, 7671,194]$} & ,150 & 699 \\
\hline & Firm age &, 165 & ,283 & $\begin{array}{c}1,17 \\
9\end{array}$ & {$[, 6772,052]$} & ,339 & ,561 \\
\hline & Constant & $-1,644$ & ,610 & 193 & & 7,256 &, 007 \\
\hline & \multicolumn{7}{|c|}{ Model-3: Bankruptcy $=-1.644-0.044 *$ marketing $+0.165 *$ firm age } \\
\hline \multirow[t]{4}{*}{ Slovakia } & Marketing & 152 & ,187 & $\begin{array}{c}1,16 \\
4\end{array}$ & {$[, 8061,680]$} & ,657 & ,418 \\
\hline & Firm age & 157 & ,353 & $\begin{array}{c}1,17 \\
0\end{array}$ & {$[, 5852,338]$} &, 198 & ,657 \\
\hline & Constant & $-2,302$ & ,780 &, 100 & & 8,717 & ,003 \\
\hline & \multicolumn{7}{|c|}{ Model-3: Bankruptcy $=-2.302+0.152 *$ marketing $+0.157 *$ firm age } \\
\hline \multirow[t]{4}{*}{ Hungary } & Marketing &,- 011 & ,169 & ,989 & {$[, 7101,379]$} & ,004 & ,949 \\
\hline & Firm age &,- 712 & ,316 & ,491 & {$[, 264,912]$} & 5,067 &, 024 \\
\hline & Constant &,- 891 & ,688 & ,410 & & 1,675 & , 196 \\
\hline & \multicolumn{7}{|c|}{ Model-3: Bankruptcy $=-0.891-0.011 *$ marketing $-0.712 *$ firm age } \\
\hline
\end{tabular}

The only significant result that this research finds is in the Hungarian sample. As illustrated in Table 5, the $p$-value for firm age is significant at a 5\% level of significance $(p=0,024<0,05)$; thus, firm age makes a significant contribution to Hungarian SMEs' bankruptcy. However, since the coefficient is negative $(\beta=-0,712)$, greater values from firm age are associated with lower possibilities to go to bankruptcy. Older Hungarian SMEs are less likely to face bankruptcy when comparing with their younger counterparts. If a firm increases by a unit, its bankruptcy will decrease by 0,712. In the case of the odds ratio of firm age, older Hungarian SMEs 0.491 times less likely to be bankrupt than their younger counterparts. However, this fact is not possible for Czech and Slovak firms since age is not a significant predictor for these SMEs' bankruptcies. To sum up, since both of the independent variables in Model-3 for Czech and Slovak SMEs are not significant and because of having nonsignificant findings from the usage of technology-enabled marketing tools in Model-3 for Hungarian SMEs, this research does not support the $\mathrm{H} 3$ hypothesis that presumes the negative relationship between the usage of technology-enabled marketing tools by older SMEs and their bankruptcy. Thus, the Binary Logistic analysis results make the researchers accept none of this paper's created hypotheses.

\section{Discussion}

As confirmed by the analyses, there are no significant relationships between the usage of technologyenabled marketing tools by SMEs and their bankruptcies. For this reason, the results of this paper opposed to the findings of Milosevic et al. (2019), Wei et al. (2018), Amjad et al. (2020), and Pineiro-Sanchez (2020). These studies confirmed the negative relationship between these variables. This paper does not find any relationship between these variables related to the industry that these businesses operate. SMEs' sectors can affect the adoption and usage of digital marketing channels by SMEs (Taiminen \& Karjaluoto, 2015). Compared to other industries, the mining and ironing industry firms are less likely to apply useful marketing tools than other 
industries (Kwilinski et al., 2020; Zaloznova \& Trushkina, 2018). Firms in these industries are less likely to be adapted to the existing marketing tools (Kwilinski et al., 2020) since they mostly make investments for energysaving projects (Wang et al., 2017). The research data firms might not have made enough investment for their marketing process; thus, they might not have increased their income and revenues to overcome bankruptcy issues.

Concerning Model-2, since both of the independent variables, usage of technology-enabled marketing tools and size of businesses are together not significant in any Model-2 for Czech, Slovakia, and Hungary, this research confirms the fact that there is not any significant association between the usage of technology-enabled marketing tools by larger sized SMEs and their bankruptcy. On the other hand, as already stated in the Results section, firm size is a determinant factor for the bankruptcy of Czech and Slovak SMEs. Compared to SMEs from both countries, smaller Czech SMEs are less likely to go to bankruptcy, while this fact is contrary to the analyzed Slovak enterprises. For these reasons, the results of this paper regarding the Czech sample comply with the studies of Cultrera and Bredart (2016), Higashi et al. (2020), and Lucanera et al. (2020) since these studies also substantiate the negative association between firm size and bankruptcy of businesses. On the other hand, since this paper finds no significant results for Hungarian SMEs depending on their size and bankruptcy and proves that older Slovak SMEs are more likely to go to bankruptcy, these results contradict the studies' results above-mentioned. The reasons for these differences might stem from credit conditions or the volume of financing in these analyzed countries. For instance, the volume of credits provided to Czech, Slovak, and Hungarian SMEs were 3.55, 3.46, and 10.69 billion euros, respectively. Since Hungarian SMEs of all sizes might have had more opportunities to gain credits, this might be why the firm's size is not a significant predictor to estimate SMEs' bankruptcy in this country.

On the other hand, the reason why Czech smaller-sized enterprises face reduced bankruptcy issues might relate to owners/entrepreneurs' age. Comparing to larger sized Czech SMEs, there are more older owners/entrepreneurs in smaller sized Czech SMEs. Since older entrepreneurs are less likely to face bankruptcy issues (Mayr et al., 2020), this might be mounting evidence to explain the differences between smaller-larger SMEs' bankruptcy in Czechia.

Model-3 considers using technology-enabled marketing tools with firm age to predict firm bankruptcy; this study proves that both independent variables are not significant together. Thus, there is no relationship between technology-enabled marketing tools by older SMEs and their bankruptcy. Moreover, this study does not find differences between Slovak and Czech SMEs' age and their bankruptcy. This fact makes this research object to Cultrera and Bredart's (2016) findings and Lucanera et al. (2020) since these studies corroborate the negative relationship between firms' age and their bankruptcies. On the other hand, since younger Hungarian SMEs are more likely to go bankrupt than their older counterparts, this paper's result regarding firm age and bankruptcy is compatible with the studies mentioned above. The reason why older-younger Czech and Slovak SMEs do not differ regarding bankruptcy might be related to owners-entrepreneurs' managerial experiences and competencies. The lack of managerial experiences and capabilities makes SMEs more likely to face bankruptcies (Tobback et al., 2017; Mayr et al., 2020). In this regard, Czech and Slovak owners and entrepreneurs might have had enough managerial experiences and abilities to overcome bankruptcy issues as their older counterparts do. This fact might be significant evidence to support these results.

To sum up, this paper's results might stem from the industry that businesses operate, the volume of financing in these analyzed countries, and the age and managerial experiences of the entrepreneurs and owners of SMEs. According to Statista (2019), the volumes for advertisements were 122 million euros in Czechia, 195 million euros in Hungary, and 163 million in Slovakia. Comparing to other advanced nations such as the USA, China, and other advanced European economies, the volumes of the analyzed nations regarding advertising are low (Statista, 2019). Therefore, these nations' politicians and governments need to apply appropriate policies to stimulate the businesses' marketing activities. Moreover, to increase company executives' managerial competencies, governments collaborate with universities to provide educational courses that include some practical activities. This training also needs to be designed by considering solutions to company executives' bankruptcy issues during their operations. Except for these implementations, political, legal, and economic systems should be tailored by the bankruptcy laws to force businesses to operate in a better-qualified environment.

\section{Conclusions}

Although SMEs' contributions might not be underestimated in nations' economic development, their financial distress might not be ignored. As bankruptcy is one of SMEs' main concerns in their survival, finding the solution for this obstacle is greatly valuable. In this regard, this paper aims to find an association between the usage of technology-enabled marketing tools by older-younger, larger-smaller sized SMEs and their bankruptcies. Since there is an increasing demand for the adaptation of new marketing technologies by businesses, analyzing technology usage and bankruptcy of SMEs in iron and mining industries of various nations 
such as Czechia, Slovakia and Hungary also fulfill the related gap literature makes this paper differ from other studies.

The researchers gained the research data by directing a questionnaire survey to randomly selected businesses from the Cribis database. The links on the same questionnaires were sent to the respondents by email, and 454 Czech, 303 Slovak, and 399 Hungarian SMEs fulfilled the survey. The researchers run Binary Logistic Regression Tests to analyze the associations between the selected variables. Moreover, the Durbin Watson test, VIF and tolerance scores, interaction terms were considered by the scholars to fulfill the assumption of the Binary Logistic Regression test.

Regarding this paper's results, there is no significant association between the usage of technology-enabled marketing tools by SMEs and their bankruptcies. The industry of the businesses might be the reason to explain this result. Moreover, the nonexistence of the relationship between technology-enabled marketing tools by larger-older and smaller-larger SMEs and their bankruptcy have also been proved by the analyses. The only significant results that this paper has found are related to firms' age, size, and bankruptcy. For instance, larger Czech SMEs have gone to bankruptcy more than smaller SMEs, while this is quite the opposite for Slovak SMEs since smaller Slovak firms have gone to bankruptcy more than their larger counterparts. No relationship exists between the size of Hungarian SMEs and their probability of going to bankruptcy. SMEs' financing volume and owners/managers' age might be mounting evidence to support this result.

Concerning the firm age, while age is not a significant predictor for the bankruptcy of Czech and Slovak SMEs, older Hungarian SMEs face lower bankruptcies than their younger counterparts. The reason for these results might be related to the managerial abilities and experiences of SMEs' executives. To conclude, the similarities and differences in the usage of technology-enabled marketing tools by older-younger, smaller-larger SMEs might be explained by owner-manager characteristics such as age and managerial experiences and financing opportunities in these countries. Therefore, governments should perform efficient strategies to provide financial and educational support for these businesses to increase their usage of technology-enabled marketing tools and decrease their probabilities to face bankruptcy problems.

Although this paper makes significant contributions to the existing literature, it has some limitations. New studies might increase the number of respondents, countries, and characteristics of businesses. Moreover, new studies can include owner-manager characteristics into the analyses to compare company executives and their perceptions of bankruptcy and usage of technology-enabled marketing tools.

\section{References}

Ajaz Khan, K., Çera, G., Nétek, V. (2019). Perception of the selected business environment aspects by service firms. Journal Of Tourism And Services, 10(19): 111-127. https://doi.org/10.29036/jots.v10i19.115.

Amjad, T., Rani H. B. A., \& Saatar, S. B. (2020). Entrepreneurship development and pedagogical gaps in entrepreneurial marketing education. The International Journal of Management Education, 18(2), https://doi.org/10.1016/j.ijme.2020.100379.

Belas, J., Amoah, J., Petráková, Z., Kliuchnikava, Y., \& Bilan, Y.(2020).Selected Factors of SMEs Management in the Service Sector. Journal of Tourism and Services,21(11), 129-146. doi:10.29036/jots.v11i21.215.

Cultrera, L. \& Bredart, X. (2016). Bankruptcy prediction: The case of Belgian SMEs. Review of Accounting and Finance, 15(1), 101-119. DOI: 10.1108/RAF-06-2014-0059.

Delerue, H. \& Cronje, T. (2015). Network technology adoption by us biotechnology firms: A Contextual approach of social media applications. International Journal of Innovation Management, 19(5), https://doi.org/10.1142/S1363919615500474.

Dobbs, M. E., Boggs, D. J., Grünhagen, M., Palacios, L. L., \& Flight, R. L. (2014). Time will tell: Interaction effects of franchising percentages and age on franchisor mortality rates. The International Entrepreneurship and Management Journal, 10(3), 607-621.

Dvorský, J., Petráková, Z., Fialová, V.(2020). Perception of business risks by entrepreneurs according to experience with the business failure. International Journal of Entrepreneurial Knowledge, 8(1), 76-88. doi: 10.37335/ijek.v8i1.104

Dvorský, J., Ključnikov, A., \& Polách, J. (2020). Business risks and their impact on business future concerning the entrepreneur's experience with business bankruptcy: case of Czech Republic. Problems and Perspectives in Management, 18(2), 418-430. doi:10.21511/ppm.18(2).2020.34

Eurostat Statistics, (2017). Number of SMEs and employees in mining and quarrying industries. Retrieved from https://ec.europa.eu/eurostat/statistics-explained/index.php/Mining_and_quarrying_statistics__NACE_Rev. 
Exposito, A., Fernández-Serrano, J. \& Liñán, F. (2019). The impact of open innovation on SMEs' innovation outcomes: New empirical evidence from a multidimensional approach. Journal of Organizational Change Management, 32(5),558-577. https://doi.org/10.1108/JOCM-09-2018-0253.

Eze, S.C., Chinedu-Eze, V.C., Bello, A.O., Inegbedion, H., Nwanji, T. \& Asamu, F. (2019). Mobile marketing technology adoption in service SMEs: a multi-perspective framework. Journal of Science and Technology Policy Management, 10(3), 569-596. https://doi.org/10.1108/JSTPM-11-2018-0105.

Field, A. (2009). Discovering Statistics Using SPSS. Sage Publications, Third Edition.

Higashi, S. Y., Caleman, S. M. D., de Aguiar, L. K., \& Manning, L. (2020). What causes organizations to fail? A review of literature to inform future food sector (management) research. Trends in Food Science \& Technology, 101, https://doi.org/10.1016/j.tifs.2020.05.011.

Hudakova, M., Masar, M., Luskova, M., \& Patak, M. R. (2018). The Dependence of Perceived Business Risks on the Size of SMEs. Journal of Competitiveness, 10(4), 54-69. https://doi.org/10.7441/joc.2018.04.04

Khan, K.A., Dankiewicz, R., Kliuchnikava, Y., \& Oláh, J. (2020). How Do Entrepreneurs Feel Bankruptcy? International Journal of Entrepreneurial Knowledge, 8(1), 89-101. doi:10.37335/ijek.v8i1.103

Kumar, P., Kumar, V. \& Mishra, J. M. (2015). A prospective study on online marketing of Small and Medium enterprises (SMEs) of services sector in India. International Journal of Applied Research ; 1(9): 910-914.

Kozubíková, L., Homolka, L., \& Kristalas, D. (2017). The effect of business environment and entrepreneurs' gender on perception of financial risk in the SMEs sector. Journal of Competitiveness, 9(1), 36-50. https://doi.org/10.7441/joc.2017.01.0

Kwilinski, A., Zaloznova, J., Trushkina, N., \& Rynkevych, N. (2020). Organizational and methodological support for Ukrainian coal enterprises marketing activity improvement. II International Conference Essays of Mining Science and Practice, E3S Web Conf., 168, 00031, https://doi.org/10.1051/e3sconf/202016800031.

Long, J. S. (1997). Regression Models for categorical and limited dependent variables. Thousand Oaks, CA, 1997, Sage Publications.

Lucanera, J. P., Fabregat-Aibar, J., Scherger, V. \& Vigier, H. (2020). Can the SOM analysis predict business failure using capital structure theory? Evidence from the subprime crisis in Spain. Axioms, 9, 46. doi:10.3390/axioms9020046.

Madill, J., Neilson, L. C., \& Haines, H. G. (2010). Web site utilization in SME business strategy: The case of Canadian wine SMEs. Journal of Small Business \& Entrepreneurship, 23(4):489-508. DOI: 10.1080/08276331.2010.10593497.

Mabenge, B. K., Ngorora-Madzimure, G. P. K., \& Makanyeza, C. (2020). Dimensions of innovation and their effects on the performance of small and medium enterprises: the moderating role of firm's age and size. Journal of Small Business \& Entrepreneurship. DOI: 10.1080/08276331.2020.1725727.

Mayr, S., Mitter, C., Kucher, S. \& Duller, C. (2020): Entrepreneur characteristics and differences in reasons for business failure: evidence from bankrupt Austrian SMEs, Journal of Small Business \& Entrepreneurship, DOI: 10.1080/08276331.2020.1786647.

Mc Namara, A., O'Donohoe, S. \& Murro, P. (2019). Lending infrastructure and credit rationing of European SMEs, The European Journal of Finance, 1-17, DOI: 10.1080/1351847X.2019.1637357

Milosevic, I., Nenad, M. I., \& Stojanovic, A. (2019). Dominant factors of SMEs failure - Multigroup Confirmatory Factor Analysis. Serbian Journal of Management, 14(2). DOI: 10.5937/sjm14-23536.

Pineiro Sanchez, C. (2020). IT resources and business survival: competitive advantage revisited. Estudios de Economía, 47(1), 79 - 125.

Rasiah, R., Kaur, K. \& Kumar, A. (2010). Does firm size matter in export, technology, and marketing activities of Indian garment firms? Asian Journal of Technology Innovation, 18(1), 45-71, DOI: 10.1080/19761597.2010.9668682.

Soltani, S., Azadi, H. \& Witlox, F. (2013). Technological innovation drivers in rural small food industries in Iran. Journal of International Food \& Agribusiness Marketing, 25(1), 68-83. DOI: 10.1080/08974438.2013.726194.

Statista, (2019). Spending on advertising in the Czech, Slovak Republic and Hungary from 2007 to 2019 , by medium (in million euros). Retrieved from https://www.statista.com/statistics/491853/advertising-spendby-medium-slovak-republic/, https://www.statista.com/statistics/491764/advertising-spend-by-mediumczech-republic/, https://www.statista.com/statistics/491779/advertising-spend-by-medium-hungary/.

Susi, V. \& Lukason, O. (2019). Corporate governance and failure risk: evidence from Estonian SME population. Management Research Review, 42(6), 703-720. https://doi.org/10.1108/MRR-03-2018-0105

Svabova, L., Michalkova, L., Durica, M. \& Nica, E. (2020). Business failure prediction for Slovak small and medium-sized companies. Sustainability, MDPI, 12(11), 1-14.

Taiminen, H., \& Karjaluoto, H. (2015). The usage of digital marketing channels in SMEs. Journal of Small Business and Enterprise Development, 22(4). https://doi.org/10.1108/JSBED-05-2013-0073. 
Tobback, E., Bellotti, T., Moeyersoms, J., Stankova, M., Martens, D. (2017). Bankruptcy prediction for SMEs using relational data. Decision Support Systems, 102, 69-81, https://doi.org/10.1016/j.dss.2017.07.004.

Wang, Y., Li, H., Song, Q. et al. (2017). The consequence of energy policies in China: A case study of the iron and steel sector. Resources Conservation and Recycling, 117, 66-73.

Wei, Y., Wang, C., Zhu, S., Xue, H., Chen, F. (2018). Online purchase intention of fruits: Antecedents in an integrated model based on technology acceptance model and perceived risk theory. Front Psychol., 23;9:1521. doi: 10.3389/fpsyg.2018.01521.

Zaloznova Y., \& Trushkina N. (2018). Mechanism for the implementation of public private partnership during management of marketing activity of enterprises in the coalmining industry. Research Papers in Economics and Finance, 3(1), 27-35. DOI: 10.18559/ref.2018.1.3. 